\title{
The Chronically Reserpinized Rat as a Possible Model for Cystic Fibrosis. VII. Alterations in the Secretory Response to Cholecystokinin and to Secretin from the Pancreas in Vivo
}

\author{
JOEL PERLMUTTER AND J. RICARDO MARTINEZ ${ }^{(22)}$
}

WITH THE TECHNICAL ASSISTANCE OF A. M. MARTINEZ AND C. COOPER

Department of Child Health, University of Missouri, School of Medicine, Columbia, Missouri, USA

\section{Summary}

The chronically reserpinized rat has been proposed as an animal model for cystic fibrosis on the basis of morphologic and secretory alterations in the submaxillary gland and of abnormalities in pulmonary secretions. In this investigation, the volume and composition of pancreatic juice from reserpine treated rats $(0.5 \mathrm{mg} / \mathrm{kg} /$ day) have been compared to those of untreated controls after stimulation with purified cholecystokinin $(0.1 \mu \mathrm{g} /$ kg body wt) and with crude and purified preparations of secretin $(6 \mu / 100 \mathrm{~g}$ body $w t)$ infused iv for 30 -min periods. The results demonstrate that the treated animals secreted a significantly lower volume of pancreatic juice after stimulation with these secretagogues. Flow rates were also significantly reduced after stimulation with cholecystokinin and crude secretin. Protein and amylase outputs in response to cholecystokinin were smaller than in control animals after unrestricted feedings, but greater after a 24-hr fast. Total bicarbonate output was also reduced after stimulation with either crude or purified secretin and the normal excretion patterns for bicarbonate and chloride were either absent or reversed in the secretin-stimulated pancreatic juice of the treated animals. Whole pancreas homogenates from the treated animals showed significant increases in $\mathrm{Ca}^{++}$and protein content. These results indicate that chronic administration of reserpine alters the secretion of water, protein, and bicarbonate from the rat pancreas and that it affects several of the exocrine glands involved in cystic fibrosis. These findings lend support to the concept of an animal model for the human disease.

\section{Speculation}

The chronic administration of reserpine to rats has been shown to induce alterations in salivary and pulmonary secretions which resemble those seen in patients with cystic fibrosis. The concept of an animal model has been proposed on the basis of these observations. The pancreas is another exocrine gland prominently involved in cystic fibrosis and if it can be demonstrated that reserpine administration also induces alterations in pancreatic secretion, the concept of the animal model would be strengthened considerably.

The generalized exocrine gland dysfunction which is characteristic of cystic fibrosis (3) has been partially reproduced in experimental animal models induced by treating rats in a chronic fashion with certain drugs that influence the level of autonomic input into these tissues. In the first of these models, changes in the excretion of monovalent ions and of basic proteins from the rat parotid gland were observed after chronic administration of isoproterenol (8). In the second model, we have demonstrated that administration of reserpine for several days induces morphologic and secretory changes in the rat submaxillary gland which resemble those of cystic fibrosis (CF) $(11,12)$. In addition, we have shown that this procedure increases the secretion of total protein and of a specific type of glycoprotein from the lungs of the treated animals, in a manner that parallels the abnormalities seen in lavage specimens from $C F$ patients (16). Preliminary evidence also indicated that pretreatment with this drug induces morphologic changes in the pancreas, characterized by acinar filling and distention and by the presence of frequent intraductal precipitates (6). The latter observation suggests that reserpine administration may also affect pancreatic function and, together with the findings on salivary and pulmonary secretions, that it may cause a generalized, rather than a selective, exocrine gland dysfunction in the rat and result in a more complete animal model for the human disease. In this investigation, therefore, we have compared the volume and composition of pancreatic juice secreted in response to cholecystokinin and to secretin stimulations in rats treated with seven daily doses of reserpine and in untreated controls.

\section{MATERIALS AND METHODS}

Male, albino rats of the Sprague-Dawley strain were used. Some animals were treated with seven daily doses of reserpine $(0.5 \mathrm{mg} / \mathrm{kg}$ body $\mathrm{wt})$ as previously described $(11,12)$ and others, housed in the same quarters and given the same standard pelleted diet and water ad libitum, were used as untreated controls. A number of animals from each group was allowed free access to food until the day of the experiments, but others were fasted for $24 \mathrm{hr}$ prior to sacrifice. On the day of the experiment, the animals were anesthetized with sodium pentobarbital (6-8 mg/100 g body wt ip) and cannulas were inserted in the trachea and in the jugular vein. Body temperature was maintained throughout the experiment by keeping the animals in a heated operating table, and the intestines and other viscera were covered with mineral oil to avoid dryness and evaporation. A midline incision was made in the abdomen and the skin was retracted in the upper half of the cavity. The duodenum was identified and lightly raised and the distal portion of the common bile duct was carefully dissected as it entered the serosal side of the medial part of the duodenum. There is no main pancreatic duct in the rat but, rather, larger ducts from pancreatic lobules drain into the common bile duct, which extends from the hilum of the liver to the duodenum. The proximal (hepatic hilum) end of this duct was exposed and loose ligatures were passed around. it and around its distal (duodenal) end. An incision was made at this end under $20 \times$ magnification using a Leitz stereo dissecting 
microscope and a piece of polyethylene tubing (Clay Adams, PE-10) was inserted for a distance of 1-2 mm and securely tied in place. Spontaneous flow of bile-containing secretion began immediately but decreased when the hepatic end of the duct was ligated. Spontaneous secretion was allowed to continue until the fluid coming out at the tip of the cannula was clear. Rates of flow during basal conditions varied in different animals, and the period for collection of this spontaneous secretion was between 30 and $70 \mathrm{~min}$. One of two samples of clear pancreatic juice were collected from the gland prior to stimulation and, subsequently, an intravenous infusion of the appropriate secretagogues was started through the jugular cannula by means of a constant infusion pump. The infusion was continued for approximately $30 \mathrm{~min}$, with slight variations depending on the weight of the animals since total dose was standardized in terms of body weight. The appropriate rate of infusion was obtained by adjusting the velocity of the pump. Pancreatic juice samples were collected at timed intervals during the period of secretagogue infusion and for 1.5-2.5 hr after infusions had been stopped. All samples were collected under oil in preweighed, tared microsample tubes placed in ice. At the end of the individual collection periods, the tubes were reweighed to obtain a gravimetric estimate of the amount of pancreatic juice secreted. Secretion was allowed to continue until the flows approached prestimulation levels and the duration of the total secretory response was recorded. The animal was killed at the end of the experiment, the pancreas was carefully removed, blotted, and weighed to the nearest milligram in a top loading balance. Rates of flow of pancreatic juice were expressed as milligram per min per $g$ wet pancreas wt. The excised pancreas was homogenized in $10 \mathrm{ml}$ ice-cold water in a Polytron homogenizer.

The following determinations were made in the juice samples: (1) total protein, by the biuret method of Lowry (7); (2) amylase, by a colorimetric method that compares the difference in absorbance of a starch-iodine complex in the sample vs. that of a blank (Harleco Co., Gibbstown, NJ, amylase reagent set no. 64191). An amylase unit is defined as the amount of enzyme that will hydrolyze $10 \mathrm{mg}$ starch in $30 \mathrm{~min}$; (3) $\mathrm{Na}^{+}$and $\mathrm{K}^{+}$in an IL flame photometer (Instrumentation Laboratories, Lexington, MA) with lithium internal standard; (4) $\mathrm{HCO}_{3}{ }^{-}$concentration in a Natelson microgasometer using a sample volume of 10 $\mu 1 ;(5) \mathrm{Cl}^{-}$concentration in a Buchler chloride titrator (Buchler Instruments, Fort Lee, NJ) using a sample volume of 5-10 $\mu$ l. Similar chemical analyses were made in the homogenates of resting (non-stimulated) and poststimulation pancreas tissue obtained from control and treated animals. In addition, the $\mathrm{Ca}^{++}$content of these tissues was measured in a Corning Instruments calcium analyzer (Corning Instruments, Medfield, MA).

The following preparations were used to stimulate pancreatic secretion: (1) A synthetic octapeptide of cholecystokinin, kindly provided by E. R. Squibb and Sons, Princeton, NJ (this preparation (SQ19844, batch UTA $860 \mathrm{H} / \mathrm{TJ} 5$ ) was dissolved in bicarbonate-saline $(0.1 \mu \mathrm{g} / \mathrm{ml})$ and stored at $-20^{\circ}$. Preliminary experiments were performed to determine the optimal rate of infusion, in order to prevent an excessive dose that would cause an irreversible inhibition of flow. A dose of $0.01 \mu \mathrm{g} / 100 \mathrm{~g}$ body wt was found to induce optimal secretory responses in our animals, (2) Porcine secretin was obtained from Calbiochem (La Jolla, CA). This product has a potency of 80-120 CrickHarper-Raper Units $/ 10 \mathrm{ml}(1.1 \mathrm{U} / \mathrm{mg})$ and is contaminated with other hormones. The dose of this compound was $6.0 \mathrm{U} / 100 \mathrm{~g}$ body wt. (3) GIH secretin was obtained from the Gastrointestinal Hormone Laboratory of the Karolinska Institute, Stockholm, Sweden. Each vial contained approximately 75 clinical units of purified natural porcine secretin, equivalent to 600650 Crick Harper units. The preparation is said to be uncontaminated with cholecystokinin and was dissolved in sterile saline and used in a dose of $6 \mathrm{U} / 100 \mathrm{~g}$ body wt. Statistical comparison of the results was made by applying Student's test to means and to standard deviations. Calculations were made in an OlivettiProgramma desk computer. A $P$ value of 0.05 or less was considered to be significant.

\section{RESULTS}

\section{CHOLECYSTOKININ STIMULATION}

The response to the synthetic octapeptide of cholecystokinin (OP-CCK) in control and reserpine treated rats was analyzed on the basis of approximately equal times of secretion, as illustrated in Table 1. This table also illustrates the total volume of pancreatic juice secreted and the maximum flow rates attained in each group of animals. Both of these values were significantly lower in the reserpine-treated rats, regardless of their feeding status. In animals fed ad libitum, the total volume of juice secreted by the treated animals was less than one-half of that produced by untreated rats. The maximum flow rate attained was also lower in the reserpine-treated animals $(P<0.05)$.

The excretion of protein and amylase after stimulation with the octapeptide of cholecystokinin is summarized in Table 2. In fed animals, treatment with reserpine resulted in a significantly lower total protein output $(P<0.05)$ and a significantly reduced total amylase output $(P<0.05)$. These two values were calculated by adding the total amount of protein or of amylase in each individual sample collected in the course of the experiment to obtain a total output for that particular animal and by averaging the values thus obtained for all experiments. After a 24-hr fast, however, the changes observed in fed rats were reversed and both the total protein output and the total amylase output in response to OP-CCK were higher in the reserpinetreated animals.

Table 1. Secretory response to cholecystokinin

\begin{tabular}{lcccc}
\hline $\begin{array}{c}\text { Experimental } \\
\text { conditions }\end{array}$ & $n$ & $\begin{array}{c}\text { Duration of } \\
\text { response, } \\
\text { min }\end{array}$ & $\begin{array}{c}\text { Total vol, } \\
\mathrm{mg}\end{array}$ & $\begin{array}{c}\text { Maximum } \\
\text { flow rate } \\
\mathrm{mg} / \mathrm{min} \cdot \mathrm{g}\end{array}$ \\
\hline $\begin{array}{l}\text { Fed ad libitum } \\
\text { Control }\end{array}$ & 7 & 134.4 & 155.0 & 4.40 \\
& & \pm 10.9 & \pm 36.7 & \pm 0.80 \\
Reserpine & 8 & 123.6 & 62.0 & 2.11 \\
& & \pm 11.0 & \pm 21.8 & \pm 1.01 \\
Fasted & & & & \\
Control & 8 & 130.1 & 119.7 & 3.98 \\
& & \pm 27.8 & \pm 22.9 & \pm 0.87 \\
Reserpine & 7 & 145.2 & 78.2 & 2.27 \\
& & \pm 17.6 & \pm 15.6 & \pm 0.92 \\
\hline
\end{tabular}

Table 2. Excretion of protein and amylase after cholecystokinin stimulation

\begin{tabular}{|c|c|c|c|c|c|c|}
\hline $\begin{array}{c}\text { Experimental } \\
\text { conditions }\end{array}$ & $n$ & $\begin{array}{c}\text { Total } \\
\text { protein } \\
\text { output, } \\
\text { mg }\end{array}$ & $\begin{array}{c}\text { Maximum } \\
\text { protein } \\
\text { conc, } \\
\mathrm{mg} / \mathrm{ml}\end{array}$ & $\begin{array}{c}\text { Total } \\
\text { amylase } \\
\text { output, } \\
\text { U }\end{array}$ & $\begin{array}{c}\text { Maximum } \\
\text { amylase } \\
\text { conc, } \\
\mathrm{U} / \mathrm{ml}\end{array}$ & $\begin{array}{c}\text { Maxi- } \\
\text { mum } \\
\text { amylase } \\
\text { sp act., } \\
\mathrm{U} / \mathrm{mg} \\
\text { protein }\end{array}$ \\
\hline \multicolumn{7}{|l|}{ Fed ad libitum } \\
\hline Control & 7 & $\begin{array}{r}10.70 \\
\pm 2.05\end{array}$ & $\begin{array}{r}101.8 \\
\pm 29.0 \pm\end{array}$ & $\begin{array}{r}5160 \\
+1528\end{array}$ & $\begin{array}{r}55.5 \\
\pm 29.3\end{array}$ & $\begin{array}{r}733.0 \\
\pm 121.0\end{array}$ \\
\hline Reserpine & 8 & $\begin{array}{r}5.75 \\
\pm 1.21\end{array}$ & $\begin{array}{l}110.7 \\
\pm 15.4 \pm\end{array}$ & $\begin{array}{r}1954 \\
\pm 1460\end{array}$ & $\begin{array}{r}38.7 \\
\pm 18.6\end{array}$ & $\begin{array}{r}432.0 \\
\pm 125.0\end{array}$ \\
\hline \multicolumn{7}{|l|}{ Fasted } \\
\hline Control & 6 & $\begin{array}{r}4.82 \\
\pm 1.23\end{array}$ & $\begin{array}{r}67.7 \\
\pm 17.6\end{array}$ & $\begin{array}{r}1953 \\
\pm 624\end{array}$ & $\begin{array}{r}33.4 \\
\pm 9.8\end{array}$ & $\begin{array}{r}627.0 \\
\pm 81.7\end{array}$ \\
\hline Reserpine & 6 & $\begin{array}{r}6.96 \\
\pm 1.31\end{array}$ & $\begin{array}{r}118.8 \\
\pm 16.5\end{array}$ & $\begin{array}{r}3161 \\
\pm 185\end{array}$ & $\begin{array}{r}54.2 \\
\pm 13.8\end{array}$ & $\begin{array}{r}548.0 \\
\pm 87.0\end{array}$ \\
\hline
\end{tabular}


Despite the reduced total protein output in the juice of the fed, reserpine-treated rats, however, the maximum protein concentrations observed were similar to those in the juice of control rats, as illustrated in Table 2. The maximum amylase concentrations were, however, lower in the juice of the treated animals, although the difference was not statistically significant (Table 2). As a consequence, the maximum amylase specific activity in the juice of reserpine treated animals was significantly reduced (Table 2). In fasted animals, on the other hand, both the maximum protein and the maximum amylase concentrations in the juice of the reserpine-treated group were significantly higher than in controls. As a result, the maximum amylase sepcific activities attained were not significantly different in the juice of control or reserpine treated rats (Table 2) after a 24-hr fast.

The excretion of protein and amylase after OP-CCK stimulation is further illustrated in Figures 1 and 2. The first of these shows the juice protein concentrations in fed animals in relation to rate of flow of pancreatic juice. It can be seen that they are generally higher in the juice secreted by reserpine treated rats at the different flow rates attained. Figure 2 shows the amylase specific activity of the juice as a function of flow rate in the same group of animals. This activity is lower in the juice from the treated animals at all rates of flow.

\section{SECRETIN STIMULATION}

The secretory response to the crude preparation of secretin is illustrated in Table 3. The duration of the secretory response to this secretagogue, as in the case of OP-CCK, was standardized to approximately equal times in both control and reserpinetreated rats. The total volume of pancreatic juice secreted and the maximum flow rate attained were significantly reduced in the fasted reserpine treated animals when compared to the corresponding controls. In the fed group, the total volume and the maximum flow rate, were also reduced in the reserpinetreated animals (Table 3 ).

The excretion of electrolytes in pancreatic juice after stimulation with crude secretin is illustrated in Figures 3 and 4 . The first of these figures shows the relationship of $\mathrm{Na}^{+}$and $\mathrm{K}^{+}$ concentrations to rates of flow in the pancreatic juice of control

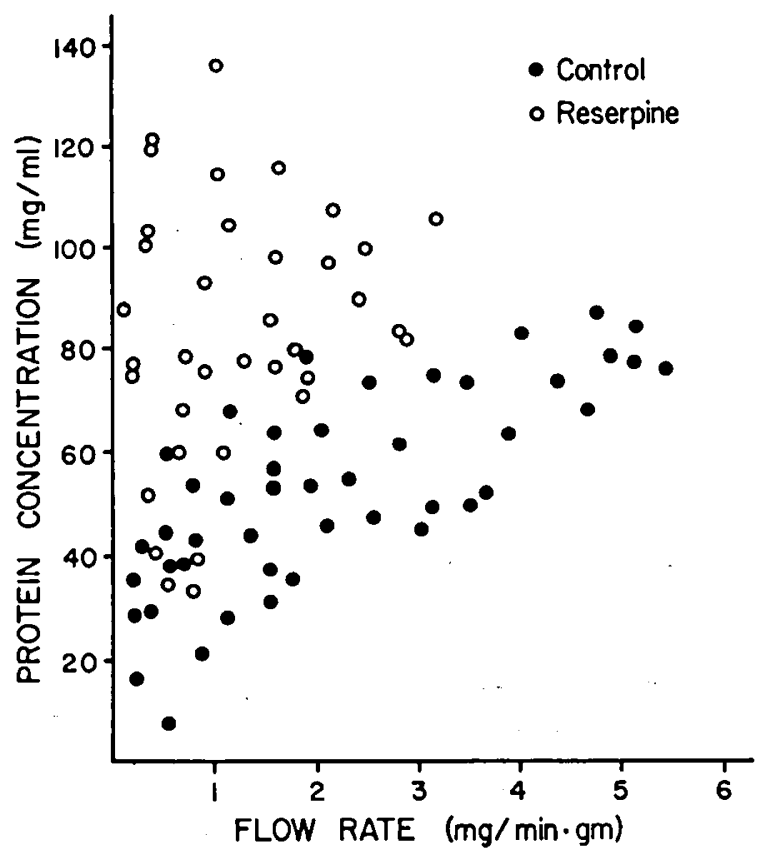

Fig. 1. Relationship between protein concentrations and flow rates in the pancreatic juice of control $(\bullet)$ and reserpine-treated rats $(O)$ after intravenous infusion of a synthetic octapeptide of cholecystokinin (OPCCK). All animals were fed ad libitum.

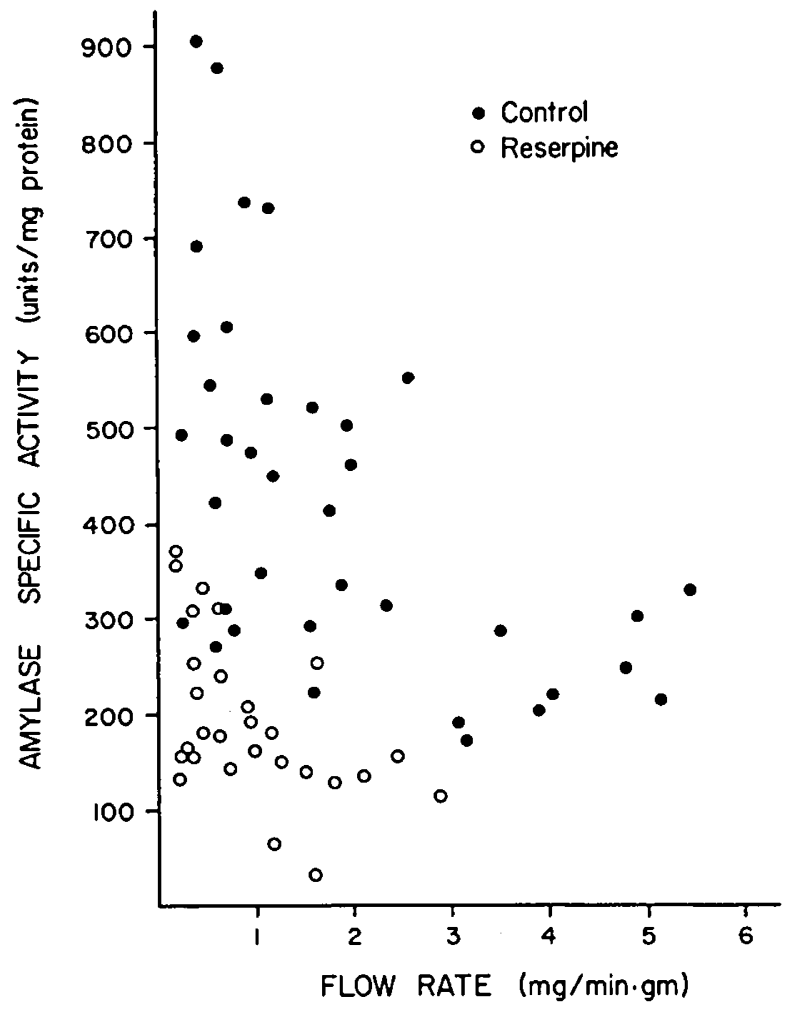

Fig. 2. Relationship between amylase specific activity and flow rate in the pancreatic juice of the same animals illustrated in Figure 1. The same symbols are used in both figures. Secretion was stimulated with $\mathrm{OP}-\mathrm{CCK}$ as in Figure 1.

Table 3. Secretory response to secretin

\begin{tabular}{lcccr}
\hline $\begin{array}{c}\text { Experimental } \\
\text { conditions }\end{array}$ & $n$ & $\begin{array}{c}\text { Duration of } \\
\text { response, } \\
\text { min }\end{array}$ & $\begin{array}{c}\text { Total vol, } \\
\mathrm{mg}\end{array}$ & $\begin{array}{r}\text { Maximum } \\
\text { flow rate, } \\
\mathrm{mg} / \mathrm{min} \cdot \mathrm{g}\end{array}$ \\
\hline $\begin{array}{l}\text { Crude secretin } \\
\text { Fed ad libitum }\end{array}$ & & & & \\
$\quad$ Control & 6 & 130.0 & 384.0 & 9.66 \\
& & \pm 6.2 & \pm 62.0 & \pm 3.26 \\
Reserpine & 7 & 129.6 & 281.0 & 7.49 \\
& & \pm 12.0 & \pm 95.1 & \pm 3.26 \\
Fasted & & 127.7 & 328.4 & 9.06 \\
Control & 6 & \pm 17.7 & \pm 36.8 & \pm 3.19 \\
& 7 & 128.3 & 207.7 & 4.69 \\
Reserpine & & \pm 21.6 & \pm 39.8 & \pm 1.39 \\
& & & & \\
GIH secretin, fasted & 5 & 125 & 222.0 & 3.99 \\
Control & & & \pm 19.0 & \pm 1.22 \\
& 6 & 125 & 136.0 & 3.00 \\
Reserpine & & & \pm 30.0 & \pm 1.02 \\
\hline
\end{tabular}

and reserpine-treated animals that were fed ad libitum. In control rats, $\mathrm{Na}^{+}$concentrations tend to decrease slightly with increasing flow rate from values of $146 \mathrm{mEq} / \mathrm{liter}$ at the lower rates to values of $135 \mathrm{mEq} /$ liter at the more rapid rates. Potassium concentrations, on the other hand, increase from 5 $\mathrm{mEq} / \mathrm{liter}$ at low flow rates to $10-12 \mathrm{mEq} / \mathrm{liter}$ at the highest rates of flow. No difference between control and reserpinetreated rats was noted in the concentrations of these cations in pancreatic juice.

Figure 4 illustrates the relationship between $\mathrm{HCO}_{3}{ }^{-}$and $\mathrm{Cl}^{-}$ concentrations and flow rate in the pancreatic juice of rats that were fasted for $24 \mathrm{hr}$. In control rats, both ions show biphasic changes with increasing rates of flow. $\mathrm{HCO}_{3}{ }^{-}$, which is approximately $40 \mathrm{mM} /$ liter at very low flows, first increases to $90 \mathrm{mM} /$ 


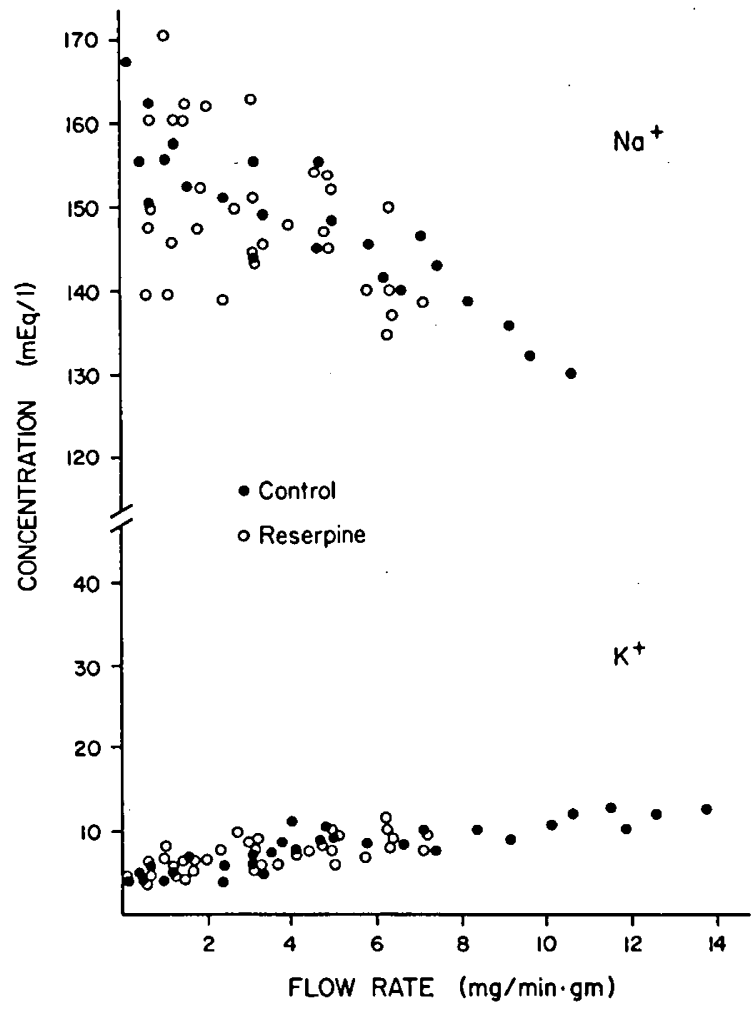

Fig. 3. Relationship between $\mathrm{Na}^{+}$and $\mathrm{K}^{+}$concentrations and flow rates in the pancreatic juice of control and reserpine-treated rats after intravenous infusion of crude porcine secretin. $\bullet$ : values obtained in control animals; $O$ : those obtained in reserpine-treated animals. All these rats were fed ad libitum.

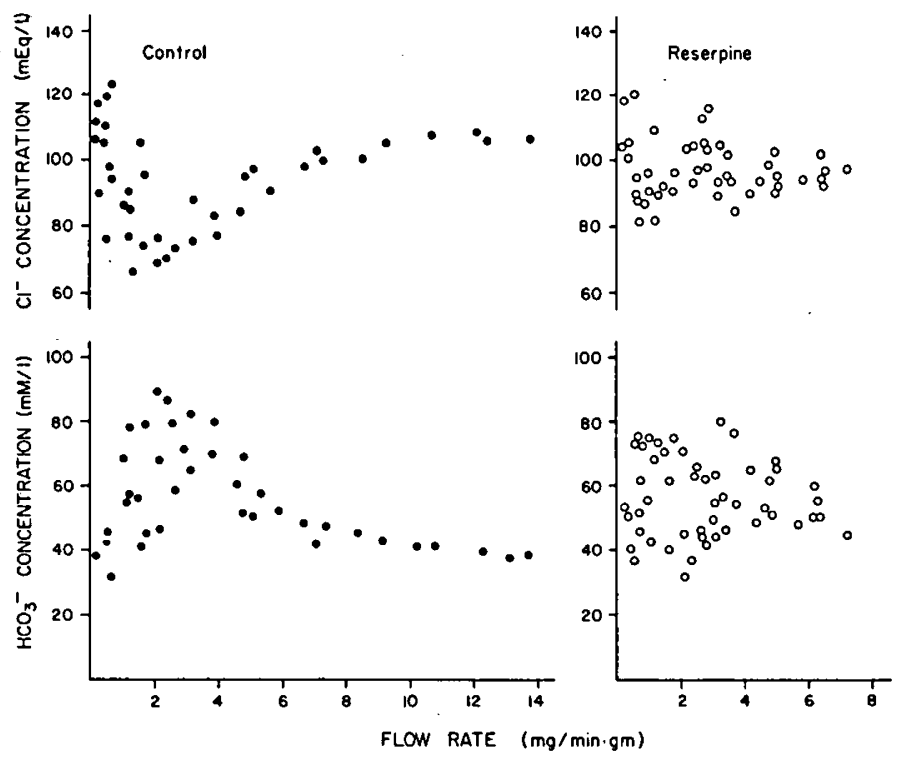

Fig. 4. $\mathrm{HCO}_{3}{ }^{-}$and $\mathrm{Cl}^{-}$concentrations as a function of flow rate in the pancreatic juice of control $(\bullet)$ and reserpine-treated rats $(O)$ after intravenous infusion of crude porcine secretion.

liter and then gradually decreases to the original levels. $\mathrm{Cl}^{-}$ concentrations are the mirror image of these, and first decrease from values of 120 to $60 \mathrm{mEq} / \mathrm{liter}$, to subsequently increase to $100 \mathrm{mEq} / \mathrm{liter}$ at the faster rates of flow. In the juice from reserpine-treated rats, this biphasic excretory pattern is absent and both anions show widely varying concentrations at all rates of flow (Fig. 4).

The secretory response to GIH secretin is also summarized in
Table 3. In these experiments, the response was selectively stopped $125 \mathrm{~min}$ after the 30 -min infusion of secretagogue was started. The total volume of juice secreted was significantly reduced in the reserpine-treated animals $(P<0.05)$, but the maximum flow rate attained, although reduced, was not significantly different from that of controls $(P<0.10)$.

The excretion of bicarbonate and chloride after purified porcine secretin (GIH secretin) was, however, abnormal in the treated animals, as illustrated in Fig. 5. In control rats, bicarbonate concentrations rise and chloride concentrations decrease with increasing rates of flow. In the treated animals, however, this excretory pattern is reversed and bicarbonate concentrations decrease while chloride concentrations increase with rising rates of flow of pancreatic juice.

The excretion of bicarbonate and chloride after crude or GIH secretin are further illustrated in Table 4 . In general, the total output of these two anions was lower in the juice of the reserpine-treated animals, regardless of their feeding status or of the preparation used to elicit secretion. This difference was statistically significant for all $\mathrm{HCO}_{3}{ }^{-}$values and for the $\mathrm{Cl}^{-}$ values observed after $\mathrm{GIH}$ secretin.

\section{PANCREAS WEIGHTS AND COMPOSITION}

Reserpine administration in the manner described causes a significant reduction in the wet weight of the resting (unstimulated) pancreas, as illustrated in Table 5. However, since there is a concomitant reduction in body weight, the ratio of pancreas weight to body weight remains unchanged in the treated animals (Table 5), regardless of their feeding status.

A comparison of the chemical composition of the unstimulated pancreas of control and of reserpine-treated rats reveals a significant increase in the $\mathrm{Ca}^{++}$and potein contents in the
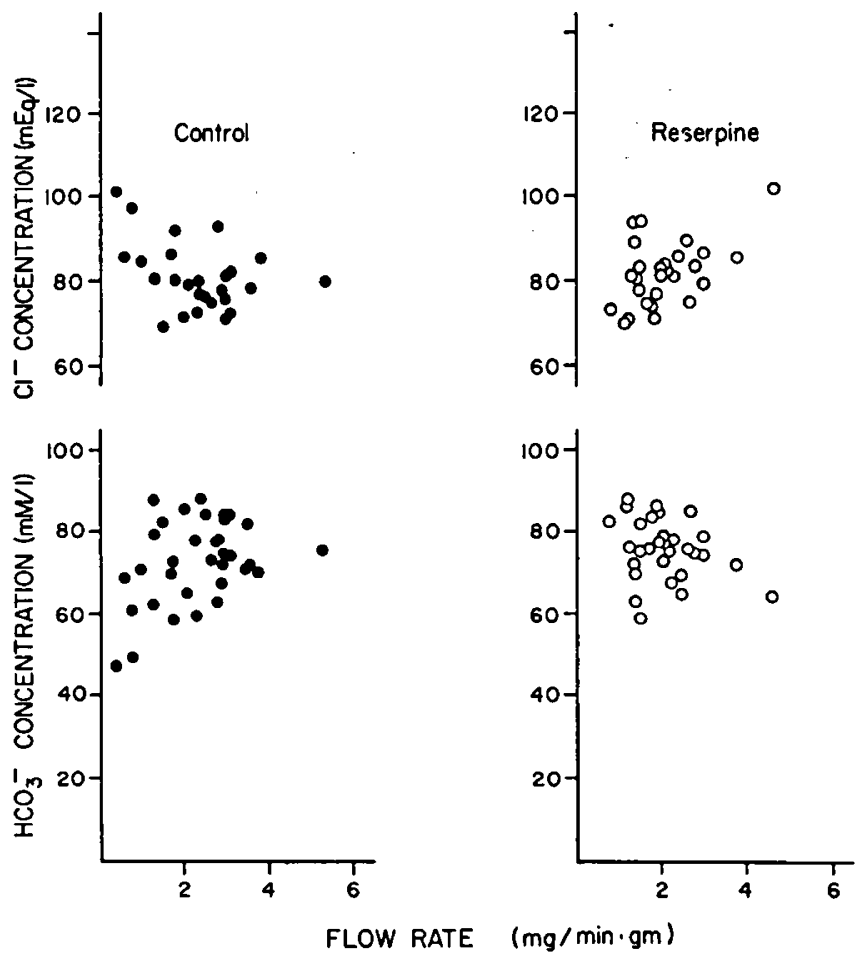

Fig. 5. $\mathrm{HCO}_{3}{ }^{-}$and $\mathrm{Cl}^{-}$concentrations as a function of flow rate in the pancreatic juice of control $(\bullet)$ and reserpine-treated rats $(O)$ after intravenous infusion of purified porcine secretin (GIH secretin). Correlation coefficients $(r)$ with flow rate were: for control rats, +0.28 for $\mathrm{HCO}_{3}{ }^{-}$and -0.68 for $\mathrm{Cl}^{-}$; for treated rats, -0.28 for $\mathrm{HCO}_{3}{ }^{-}$and +0.45 for $\mathrm{Cl}^{-}$. A statistical test for the significance of the difference between two correlation coefficients indicates a significant difference for the $\mathrm{HCO}_{3}{ }^{-}$values at the $95 \%$ confidence level and at the $99 \%$ level for the $\mathrm{Cl}^{-}$values. 
treated animals, whether they were fed ad libitum or fasted for $24 \mathrm{hr}$ (Table 5). No other significant changes were noted, although $\mathrm{Na}^{+}$and $\mathrm{K}^{+}$contents tended to be increased in the pancreas of the treated animals. Stimulation with OP-CCK did not produce significant changes in the monovalent ion content of the pancreas of fasted control and reserpine treated rats (Table 5). This secretagogue produced, however, a significant increase in the $\mathrm{Na}^{+}$content of the pancreas of control rats that were fed ad libitum, from $32.9 \mathrm{mEq} / \mathrm{kg}$ wet wt to $43.6 \mathrm{mEq} / \mathrm{kg}$ wet wt (Table 5). OP-CCK did not produce significant changes in the $\mathrm{Ca}^{++}$, protein, or amylase contents of the pancreas of either control or reserpine-treated animals, whether they were fed or fasted. In fasted animals, it tended to cause slight

Table 4. Excretion of bicarbonate and chloride after secretin stimulation

\begin{tabular}{lccc}
\hline $\begin{array}{c}\text { Experimental } \\
\text { conditions }\end{array}$ & $n$ & $\begin{array}{c}\text { Total } \mathrm{HCO}_{3}{ }^{-} \\
\text {output, } \mu \mathrm{Eq}\end{array}$ & $\begin{array}{r}\text { Total } \mathrm{Cl}^{-} \\
\text {output, } \mu \mathrm{Eq}\end{array}$ \\
\hline $\begin{array}{l}\text { Crude secretin } \\
\text { Fed ad libitum } \\
\text { Control }\end{array}$ & & & \\
$\therefore \quad$ Reserpine & 6 & 232 & 351 \\
& 6 & \pm 45 & \pm 72 \\
Fasted & & \pm 25 & 266 \\
Control & & & \pm 98 \\
& 6 & 193 & \\
Reserpine & 7 & 147 & 278 \\
& & \pm 27 & 219 \\
GIH secretin, fasted & & & \pm 64 \\
Control & 5 & 160 & 177 \\
& & \pm 23 & \pm 10 \\
Reserpine & 6 & 108 & 122 \\
& & \pm 27 & \pm 28 \\
\hline
\end{tabular}

reductions in the $\mathrm{Ca}^{++}$or protein contents of the pancreas (Table 5).

As also illustrated in Table 5, stimulation with crude secretin caused no significant changes in the composition of the pancreas homogenate in fasted control or reserpine-treated rats. In fed controls it produced, like OP-CCK, a significant increase in $\mathrm{Na}^{+}$ content. The secretagogue did not cause significant changes in the composition of the pancreas of fed, reserpine-treated rats.

Pure secretin was used in fasted animals only. As shown in Table 5, there were no significant changes in the composition of the pancreas homogenates from control and treated animals at the termination of the secretory response to this secretagogue.

\section{DISCUSSION}

The results of these experiments confirm previous observations on the response of the rat pancreas to hormonal stimulation (13-15). Both cholecystokinin and secretin elicit a characteristic secretory response and their effects on volume and composition of the pancreatic juice can be additive and explain some previously reported high flow rates obtained after in vivo stimulation with secretin preparations which were probably contaminated with CCK (9). The results also demonstrate that the chronic administration of reserpine to rats results in a reduced pancreatic secretory response to cholecystokinin and to secretin; in abnormal patterns of protein, amylase and bicarbonate secretion; in a reduced total bicarbonate output after secretin stimulation; and in changes in the composition of pancreatic homogenates, involving significant increases in $\mathrm{Ca}^{++}$and protein contents. Previous evidence from this laboratory had already demonstrated that treatment with reserpine resulted in suggestive morphologic ((11) and secretory changes (12) in the submaxillary gland of the rat. The latter involved increases in the concentrations of $\mathrm{Na}^{+}, \mathrm{Ca}^{++}$, and organic components in saliva, and the appearance of cilioinhibitory properties in this

Table 5. Composition of pancreas homogenates

\begin{tabular}{|c|c|c|c|c|c|c|c|c|c|c|}
\hline Stimulation & $\begin{array}{c}\text { Exp. } \\
\text { conditions }\end{array}$ & $\begin{array}{l}\text { Pancreas } \\
\text { wt, mg }\end{array}$ & $\begin{array}{c}\mathrm{PW} / \mathrm{BW}^{1} \\
\times 100 \\
\mathrm{mg} / \mathrm{gm}\end{array}$ & $\begin{array}{c}\mathrm{Na}^{+}, \\
\mathrm{mEq} / \mathrm{kg}\end{array}$ & $\begin{array}{c}\mathrm{K}^{+}, \\
\mathrm{mEq} / \mathrm{kg}\end{array}$ & $\begin{array}{l}\mathrm{Ca}^{++}, \\
\mu \mathrm{g} / \mathrm{mg}\end{array}$ & $\begin{array}{c}\text { Protein, } \\
\mu \mathrm{g} / \mathrm{mg}\end{array}$ & $\begin{array}{c}\text { Amylase, } \\
\text { U/mg }\end{array}$ & $\begin{array}{l}\text { Amylase } \\
\text { sp act, } \\
\text { U/mg }\end{array}$ & $n$ \\
\hline \multirow[t]{2}{*}{ Fed rats } & Control & 904 & 300 & 32.9 & 75.6 & 0.088 & 102.9 & 30.6 & 294.6 & 10 \\
\hline & & \pm 101 & \pm 36 & \pm 3.2 & \pm 8.3 & \pm 0.008 & \pm 7.8 & \pm 7.0 & \pm 67.6 & \\
\hline \multirow[t]{2}{*}{ None } & Reserpine & 465 & 278 & 41.2 & 82.8 & 0.112 & 123.7 & 28.6 & 225.2 & 10 \\
\hline & & \pm 69 & \pm 16 & \pm 5.5 & \pm 7.3 & \pm 0.008 & \pm 9.4 & \pm 7.1 & \pm 37.2 & \\
\hline \multirow[t]{2}{*}{ None } & Control & 1043 & 381 & 43.6 & 68.4 & 0.094 & 91.6 & 23.4 & 256.0 & 7 \\
\hline & & \pm 221 & \pm 42 & \pm 3.9 & \pm 8.0 & \pm 0.014 & \pm 12.8 & \pm 5.4 & \pm 61.0 & \\
\hline \multirow{2}{*}{ OP-CCK } & Reserpine & 608 & 324 & 48.9 & 82.6 & 0.128 & 118.9 & 25.5 & 229.0 & 8 \\
\hline & & \pm 82 & \pm 40 & \pm 4.2 & \pm 10.2 & \pm 0.018 & \pm 5.0 & \pm 5.3 & \pm 66.0 & \\
\hline \multirow{2}{*}{ OP-CCK } & Control & 1039 & 342 & 47.8 & 69.0 & 0.104 & 92.5 & & . & 6 \\
\hline & & \pm 207 & \pm 45 & \pm 4.8 & \pm 9.4 & \pm 0.002 & \pm 13.1 & & & \\
\hline \multirow[t]{2}{*}{ Secretin } & Reserpine & 754 & - $\quad 374$ & 49.8 & 85.3 & 0.119 & 114.0 & & & 7 \\
\hline & & \pm 175 & \pm 61 & \pm 4.3 & \pm 10.6 & \pm 0.011 & \pm 14.1 & & & \\
\hline \multirow[t]{2}{*}{ Fasted rats } & Control & 895 & 318 & 40.8 & 74.7 & 0.080 & 107.0 & 23.3 & 228.1 & 6 \\
\hline & & \pm 24 & \pm 15 & \pm 4.5 & \pm 8.2 & \pm 0.012 & \pm 2.8 & \pm 4.7 & \pm 28.2 & \\
\hline \multirow[t]{2}{*}{ None } & Reserpine & 464 & 296 & 46.4 & 83.1 & 0.112 & 139.3 & 31.6 & 264.6 & 9 \\
\hline & & \pm 27 & \pm 15 & \pm 4.7 & \pm 9.6 & \pm 0.012 & \pm 7.2 & \pm 6.9 & \pm 31.6 & \\
\hline \multirow[t]{2}{*}{ None } & Control & 939 & 397 & 46.2 & 79.2 & 0.092 & 96.8 & 26.9 & 270.3 & 8 \\
\hline & & \pm 116 & \pm 22 & \pm 5.7 & \pm 7.3 & \pm 0.006 & \pm 5.4 & \pm 4.8 & \pm 48.9 & \\
\hline \multirow[t]{2}{*}{ OP-CCK } & Reserpine & 631 & 376 & 53.1 & 84.1 & 0.105 & 128.3 & 27.3 & 205.5 & 7 \\
\hline & & \pm 108 & \pm 33 & \pm 4.5 & \pm 6.7 & \pm 0.002 & \pm 13.0 & \pm 6.7 & \pm 45.5 & \\
\hline \multirow[t]{2}{*}{ OP-CCK } & Control & 1008 & 384 & 45.0 & 73.9 & 0.096 & 102.8 & & & 6 \\
\hline & & \pm 85 & \pm 56 & \pm 6.6 & \pm 5.3 & \pm 0.015 & \pm 8.8 & & & \\
\hline \multirow[t]{2}{*}{ Secretin } & Reserpine & 710 & 399 & 43.9 & 74.9 & 0.118 & 117.8 & & & 8 \\
\hline & & \pm 101 & \pm 59 & \pm 6.9 & \pm 4.9 & \pm 0.015 & \pm 17.3 & & & \\
\hline \multirow[t]{2}{*}{ Secretin } & Control & 968 & 416 & 40.3 & 83.5 & 0.101 & 100.0 & & & 5 \\
\hline & & \pm 267 & \pm 86 & \pm 7.9 & \pm 7.2 & $\pm 0,017$ & \pm 17.0 & & & \\
\hline \multirow[t]{2}{*}{ GIH secretin } & Reserpine & 658 & 359 & 44.2 & 91.9 & 0.126 & 139.0 & & & 6 \\
\hline & & \pm 83 & \pm 49 & \pm 3.6 & \pm 11.3 & \pm 0.012 & \pm 19.0 & 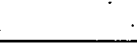 & & \\
\hline
\end{tabular}

$1 \mathrm{PW} / \mathrm{BW}$ : ratio of pancreas weight to body weight. 
secretion (12). More recent observations also demonstrated an increased concentration of protein and of a specific type of glycoprotein in lung lavage samples from the reserpine-treated animals (16). The present findings indicate that in addition, this drug causes pancreatic dysfunction and that, in the rat model, it therefore affects several of the exocrine glands which are primarily involved in cystic fibrosis.

Pancreatic secretions have not been extensively studied in the CF patient, but the available evidence indicates that in individuals relatively free of clinical symptoms of pancreatic insufficiency, the most important changes involve reduced volumes and bicarbonate outputs and variable alterations in enzyme secretion following a pancreozymin-secretin stimulus (5). It is significant, therefore, that the disturbances in pancreatic secretion *induced by reserpine in the rat also involve, primarily, reductions in water and bicarbonate outputs. Pancreatic juice is thought to be a mixture of a scanty, concentrated enzyme solution secreted by the acinar cells and of a larger volume of electrolyte-rich fluid secreted by the centroacinar or duct cells $(9,13)$. In the CF patients, the findings of Hadorn et al. (5) were explained by assuming that the "electrolyte fraction" was reduced. An overproduction of the "organic fraction" of pancreatic juice leading to mechanical obstruction of the ducts and impairment of flow was also proposed as an alternative explanation of the reduced secretory (volume) response in the CF patients. Similar mechanisms could operate in the rat pancreas following reserpine administration. Bicarbonate output is reduced after secretin stimulation and probably underlines the production of smaller volumes of fluid from centroacinar cells. In addition, obstruction of pancreatic ducts has been observed in histological sections of the pancreas from the treated rats (6) and the present findings also demonstrate both an increased protein content in pancreatic homogenates and variable outputs of protein and amylase is the juice of the treated animals.

No satisfactory explanation has been offered for the reduced bicarbonate output in the pancreatic juice of the $C F$ patient. In the reserpinized rat model, our findings suggest an impairment of the anion-exchange mechanism which is thought to occur in the pancreatic ducts of normal rats $(9,10,13)$. The loss of the biphasic pattern of bicarbonate and chloride excretion after crude secretin, and the reversal in the relationship between the concentration of these two anions and flow rate after purified secretin, suggest that the exchange is either inhibited or reversed as a result of some as yet unidentified action of reserpine on the pancreatic duct cells. More information about the exact nature of the mechanisms of anion secretion in the pancreas is required before this effect of reserpine can be delineated. The existence of anion pumps operating in the production of pancreatic fluid has been suggested, and it was found that polylysine, a positively charged synthetic polyamino acid which inhibited transductal reabsorption of $\mathrm{Na}^{+}$in the rat parotid, also eliminates the transductal fluxes which modify the anionic composition of pancreatic juice (9). No difference was noted in this study, on the other hand, in the excretion patterns of $\mathrm{Na}^{+}$and $\mathrm{K}^{+}$in the pancreatic juice of control and reserpine-treated rats. Cation exchange is not prominent in the pancreatic ducts $(9,10)$, although our results in normal rats suggest a slight, albeit noticeable, change in $\mathrm{Na}^{+}$and particularly $\mathrm{K}^{+}$concentrations (also seen in a previous study, see Reference 13) with increasing flow rates. This implied that cations may be transported to a slight extent in the pancreatic ducts but that this mechanism, if present, is not affected by the reserpine treatment.

Although reserpine is a powerful depleter of catecholamines (11), its marked effects on submaxillary gland function seem to be primarily the result of a direct toxic action on the salivary cells, involving changes in membrane permeability and in $\mathrm{Ca}^{++}$ homeostasis $(12,18)$. It is interesting, therefore, that this drug also causes an increase in the $\mathrm{Ca}^{++}$content of the rat pancreas. The possible role of this divalent cation in the stimulus-secretion coupling mechanism of pancreatic cells $(2,4,17)$, in the exocrine secretory abnormality of the CF patient (3), and in the production of cilioinhibitory effects of CF fluids (1) has been previously suggested. Changes in the $\mathrm{Ca}^{++}$homeostasis of the rat pancreas after reserpine administration could interfere with the secretory mechanisms for water, protein, and electrolytes. Alterations in the physicochemical properties of secretory proteins could also result from enhanced binding of $\mathrm{Ca}^{++}$.

In view of our previous observations in the submaxillary gland $(11,12)$ and in the pulmonary secretions $(16)$ of the reserpinetreated rat, the similarity between the disturbances in the pancreatic secretory response of the CF patient (5) and of the treated animal lends support to the view that it constitutes a useful animal model for the human disease. The relevance of this model, in contrast to the isoproterenol-treated rat (8), resides in the prominent involvement of several exocrine tissues that are affected in CF and in the importance that the marked effects of reserpine on the secretory capacity of these target tissues may have in elucidating possible pathogenetic mechanisms in CF. Although the pharmacologic actions of reserpine are complex in nature, the evidence obtained so far suggests that it interferes with secretory function by a direct effect on exocrine secretory cells, which involves a disruption of the stimulussecretion coupling mechanism in at least two aspects: the transmembrane transport of ions and organic materials and the energy sources that supply the mechanisms responsible for the extrusion of secretory components. A similar disturbance in the exocrine glands of the CF patient could explain the generalized secretory abnormalities seen in this disease.

\section{CONCLUSION}

The pancreatic secretory response to cholecystokinin and to secretin was compared in vivo between rats treated with seven daily doses of reserpine and untreated controls. It was found that the volume of pancreatic juice, and in certain cases the flow rates, were significantly reduced in the treated animals. Total bicarbonate output was also significantly reduced and the normal patterns of bicarbonate and chloride excretion were either absent or reversed in these animals after secretin stimulation. Abnormal patterns of amylase and protein excretion were observed after cholecystokinin stimulation. The pancreas of the treated animals showed an increased content of $\mathrm{Ca}^{++}$and protein. It was concluded that reserpine administration alters the secretion of water, bicarbonate, and protein from the rat pancreas. The similarity of these findings with those reported in the pancreatic juice of CF patients and the relevance of these findings to the concept of an animal model for CF are discussed.

\section{REFERENCES AND NOTES}

1. Bogart, B. J., Conod, E. J., and Conover, J. H.: The biologic activities of cystic fibrosis. I. The effects of cystic fibrosis sera and calcium ionophore A 23187 on rabbit tracheal explants. Pediat. Res., 11: 131 (1977).

2. Case, R. M., and Clausen, T.: The relationship between calcium exchange and enzyme secretion in the isolated rat pancreas. J. Physiol. (London), 235: 75 (1973).

3. Di Sant'Agnese, P. A., and Talamo, R. C.: Pathogenesis and physiopathology of cystic fibrosis of the pancreas. New Engl. J. Med., 277: 1287, 1344, 1399, (1967).

4. Eimerl, S., Savion, N., Heichal, O., and Selinger, Z.: Induction of enzyme secretion in rat pancreatic slices using the ionophore A23187 and calcium J. Biol. Chem., 249: 3991 (1974).

5. Hadorn, B., Johansen, P. G., and Anderson, C. M.: Exocrine pancreatic function in cystic fibrosis. In: D. Lawson: Proceedings of the Fifth International Cystic Fibrosis Conference, p. 55. Churchill College, Cambridge, 1969.

6. Immken, L., Martinez, J. R., Hess, R. A., and Barbero, G. J.: The chronically reserpinized rat as a possible model for cystic fibrosis. III. Histochemistry of exocrine glands. Cystic Fibrosis Club Abstracts, XVI Annual Meeting, Denver, 1975, p. 9.

7. Lowry, O. H., Rosebrough, N. F., Farr, A. L., and Randall, R. J.: Protein measurement with the Folin phenol reagent. J. Biol. Chem., 193:'265 (1961).

8. Mangos, J. A., McSherry, N. R., Benke, P. J., and Spock, A.: Studies on the pathogenesis of cystic fibrosis: The isoproterenol treated rat as an experimental model. In: A. Lawson: Proceedings of the Fifth International Cystic Fibrosis Conference, Churchill College, Cambridge, 1969.

9. Mangos, J. A., and McSherry, M. R.: Micropuncture study of excretion of 
water and electrolytes by the pancreas. Amer. J. Physiol., 221: 496 (1971).

10. Mangos, J. A., McSherry, N. A., Nousia-Arvanitakis, S., and Schilling, R. F.: Transductal fluxes of anions in the rat pancreas. Proc. Soc. Exp. Biol. Med., 146: 321 (1974).

11. Martinez, J. R., Adelstein, E., Quissell, D. O., and Barbero, G. J.: The chronically reserpinized rat as a possible model for cystic fibrosis. I. Submaxillary gland morphology and ultrastructure. Pediat. Res., 9: 463 (1975).

12. Martinez, J. R., Adshead, P. C., Quissell, D. O., and Barbero, G. J.: The chronically reserpinized rat as a possible model for cystic fibrosis. II. Composition and cilioinhibitory effects of submaxillary saliva. Pediat. Res., 9: 470 (1975)

13. Sewell, W. A., and Young, J. A.: Secretion of electrolytes by the pancreas of the anesthetized rat. J. Physiol. (London), 252: 379 (1975).

14. Shaw, H. M., and Heath, T.: The significance of hormones, bile salts and feeding in the regulation of bile and other digestive secretions in the rat. Aust. J. Biol. Sci., 25: 147 (1972).

15. Shaw, H. M., and Heath, T.: The phases of pancreatic secretions in rats. Q.J. Exp. Physiol., 58: 229 (1973).

16. Thompson, F. E., Quissell, D. O., Williams, C. H., and Martinez, J. R.: The

$0031-3998 / 78 / 1203-0188 \$ 02.00 / 0$

Copyright 01978 International Pediatric Research Foundation, Inc. chronically reserpinized rat as a possible model for cystic fibrosis. IV. The protein composition of pulmonary lavage fluid. Pediat. Res., 10: 632 (1976).

17. Williams, J. A., and Lee, M.: Pancreatic acinar cells: Use of a Ca ${ }^{++}$ionophore to separate enzyme release from the earlier steps in stimulus-secretion coupling. Biochem. Biophys. Res. Commun., 60: 542 (1974).

18. Wood, D. L., and Martinez, J. R.: The chronically reserpinized rat as a possible model for cystic fibrosis. VI. Synergistic effects of isoproterenol on $\mathrm{Ca}^{++}$and protein in the submaxillary gland. Pediat. Res. 11: 827 (1977).

19. Mr. J. Perlmutter was recipient of a Student Fellowship from the National Foundation during part of this work.

20. Dr. J. R. Martinez was recipient of a Research Scholar Award from the Cystic Fibrosis Foundation.

21. This research was supported by grants from the Cystic Fibrosis Foundation and the National Foundation.

22. Requests for reprints should be addressed to: J. R. Martinez, M.D., Department of Child Health, University of Missouri, School of Medicine, Columbia, MO 65201 (USA).

23. Received for publication February $22,1977$.

24. Accepted for publication June 10, 1977. 